\title{
STUDENT ACCULTURATION IN THE CONTEXT OF "FEESMUSTFALL"
}

\author{
R. Jogee* \\ School of Economics and Business Sciences \\ e-mail: Rubina.jogee@wits.ac.za
}

\section{N.C. Callaghan*}

Faculty of Humanities and Community Development

e-mail: tasha.postbox@gmail.com

\section{W. Callaghan*}

School of Economics and Business Sciences

e-mail: Chris.Callaghan@wits.ac.za

*University of the Witwatersrand

Johannesburg, South Africa

\section{ABSTRACT}

According to acculturation theory, acculturation orientations are determined by the interactive strength of two individual dimensions, namely (i) a desire to maintain one's own culture, and (ii) a desire to acculturate to popular culture, with combinations of these processes classified as assimilation, separation, marginalisation or integration. What is absent from the predictions of acculturation theory (which are premised on the individual level), as well as the literature, however, is a consideration of individual-level differences which are not theoretically ascribed to cultural influences, but which derive from the individual, such as those predicted by personality theory. Using a sample of 251 economics students in the context of a large South African university, we use logistic regression analysis to test theory predicting the likelihood that students fall into each of Berry's four acculturation orientations, while also testing personality dimensions as explanatory factors. We find neuroticism and age are to be negative and significant predictors of the likelihood to fall into the separation explanatory category. Women and those older than their cohorts are found to be more likely to fall into the marginalisation category. Agreeableness is negatively associated with marginalisation. We discuss the implications of these findings and derive recommendations for university management in order to improve acculturation of students in this context.

Keywords: acculturation, marginalisation, personality theory

\section{INTRODUCTION}

South Africa's student protests associated with the "FeesMustFall” movement, calling for free 
and decolonised education have seen vehicles stoned and busses set alight, as well as the violent occupation of portions of the city by crowds of protesting students (Ngcobo, Manyathela and Bateman 2016). Calls to spread the protest to other sectors, and to ultimately "make the country 'ungovernable'”, coincided with other events such as the shut-down of the Johannesburg Central Business District by a taxi blockade (Goba 2016, 1). These events occurred amidst a rise in violent service delivery protests nationwide (Mapumulo 2016).

The student protests have also seen a host of other protest-related consequences, including fatalities (Chiloane 2016; ENCA 2016; Pitjeng 2016), echoing increasing threats of violence by politicians (Vegter 2014; Manyathela 2016; Stolley 2016). Although many concerns about societal breakdown and violence in South Africa may be alarmist, the violent and ongoing student protests do have serious consequences for a developing country with little current economic growth and broader societal tensions. Given this context, the importance of research to understand the causes of these protests cannot be understated.

While the calls for free and decolonised education have led to destruction of university and other property, intimidation of university staff, and forced exit of staff from university offices (Chiloane 2016), many have questioned the cause of events, over and above concerns about fee increases. Concerns about fee increases are understandable, given South Africa's high levels of unemployment and inequality, and its oppressive history. What is less clear, however, is how the acculturation of groups (students) to a dominant culture (associated with the university itself) occurs.

Closer investigation of the "other half" of the demands of students for lower fees and decolonised education might offer important insights. The demand for decolonised education stems from the anger of students at the colonial nature of the university, its primarily "Western" paradigm of values, cultural climate (Manjra 2016; Pilane 2016). This reality is succinctly captured by Everatt $(2016,1)$ :

"Let's also accept that for many students, much of the academy is an alienating, overwhelmingly white, Eurocentric space and experience. Students arrive and are expected to meet imported norms, seminar room sarcasm, unknown customs, foreign authors, hard marking and plain hard slog of tertiary education, while being young and going through their own life transitions, and doing so in 'othered' spaces, out of vernacular, and so on.”

These protests reflect a history of student and service delivery protests, such as those across the 1970s and 1980s (Lodge and Nasson 1991; Rhoads 1998).

This study sought to understand how certain aspects of this contextual dissatisfaction might relate to the challenges of student acculturation, or cultural adaptation to university (Everatt 2016; Manjra 2016; Pilane 2016) and its potentially “alien” context. Arguably, 
acculturation of the majority of students to what might seem an alien culture might be frustrating, and knowledge of what contributes to different acculturation choices is important in that such knowledge might be used to help students adjust more effectively to the university context. Similarly, such knowledge can enable administrators to better understand what shapes the acculturation process, so that students might receive more effective support in this process. This study, however, seeks to go a step further. Although acculturation has typically been considered a psychological process of individual adaptation to culture, what is absent from the literature is consideration of individual influences such as personality in the acculturation process. This study therefore seeks to test the relative contributions of individual student characteristics together with personality endowments to the acculturation strategies of students.

According to Berry’s (2008) acculturation theory, there are two independent dimensions that underlie the acculturation process. These are (i) the extent to which individuals seek to maintain their culture and identity in the face of a dominant culture, and (ii) the extent to which they seek involvement, or adaptation to the dominant culture (Berry 2008). Individuals will typically differ in their commitment to either (i) or (ii), and this difference will then determine their choice of one of four strategies of acculturation, namely assimilation, separation, marginalisation or integration (Berry 2005). This research therefore tests the extent to which individual characteristics, including individual personality endowments, explain variance in an individual's choice of acculturation strategy. Further, the contribution of individual characteristics to an individual's preference to maintain own culture and to adapt to the university's culture are also tested.

This study seeks to make a contribution to the education literature relating to acculturation. Therefore, this research is considered important, for the following reasons. First, entering university requires adjustment or adaptation for students (Feldt, Graham and Dew 2011), and failure to adequately adjust or adapt can have consequences, including failure or dropout (Othman et al. 2013). Adaptation is necessary for optimal functioning; both for student wellbeing and the development of social skills in a culturally complex setting (Berry 2011). Knowledge of what shapes an individual's acculturation strategy is expected to contribute to support strategies for those who might experience marginalisation, as this may constrain adaptation. Constrained adaptation might give rise to certain consequences associated with poor adaptation, which might accrue to those students most vulnerable to acculturation difficulties.

Second, what is not understood in the acculturation literature is the extent to which acculturation is shaped by individual versus group factors. Assumptions of cultural homogeneity, or of an entirely cultural origin for acculturation choices might be problematic, 
as they deny the opportunity for support measures specifically tailored to the needs of individuals. Knowledge of the relative sensitivity of acculturation strategies to different individual characteristics would therefore allow for the development of an acculturation strategy typology for the individual.

Third, research on acculturation has typically focused on acculturation relating to refugees, immigrants, asylum seekers, expatriates, sojourners and the so called ethnic minorities in foreign countries (Sam and Berry 2010). The focus of this study is to investigate how first year Economics students, the majority of whom are Black (71.3\%), acculturate to university. This is considered particularly important given the discrepancy between the culture of the majority of students and that of the ostensibly Euro-centric culture of the country's universities, given the country's history, which certain aspects of these universities may typify in the eyes of many students.

Having outlined the contribution to the acculturation literature offered by the study, the article proceeds as follows. First, theory is considered that relates the variables under study. Hypotheses are then derived in order to be able to test theory. Next, the methods used in the study are explained, and the results are reported and discussed. Finally, conclusions are derived and recommendations for further research are offered. Theory which relates acculturation strategies to individual characteristics and to the theoretical context is considered as follows.

\section{THEORY AND HYPOTHESES}

Growing interest in the field of acculturation internationally has been attributed to two main issues, namely worldwide migration and the increasing need to understand linkages between culture and human behaviour in the field of cross cultural psychology (Sam and Berry 1995). In the South African context, however, the country’s Black majority have become the majority only relatively recently in the country's previously "White” universities, as under Apartheid policies of racial segregation resulted in socio-economic inequality, poverty and lack of equal access to educational opportunities (Sennett et al. 2003). Since the advent of democracy in 1994, increased access to universities by previously disadvantaged students have enabled transformation of student bodies. Although the educational context in South Africa is rapidly changing (Govinder, Zondo and Makgoba 2013), and black enrolments have increased considerably, White academic staff continue to dominate in academic positions, with the continued hegemony of Western thought and culture, in the country's institutions and curricula (Jawitz 2016).

Acculturation is defined as the cultural and psychological change that occurs when 
different cultural groups are brought into contact with other groups, which includes the ensuing adaptation that occurs on account of this process (Berry 2010). Although acculturation may also refer to changes that happen in the receiving group or society, it is mostly studied as a process of adaptation in the group that is incoming (Schwartz and Zamboanga 2008).

Universities are attracting students from all walks of life; and from different cultures (Kamsteeg and Wels 2012). University life, however, may represent a different culture for students coming from school contexts. According to Otlu (2010), the transition to the university context may be similar to the acculturation of immigrants into new societies, and this is perhaps no different for Black South Africans, who are essentially entering an institution with predominantly Euro-centric traditions and trappings. It is acknowledged that Black South African schools also include institutions and cultural artefacts, or predominantly Eurocentric traditions and trappings, and insufficient use of indigenous knowledge (Mashoko, Mushayikwa and Keane 2016), but our focus here is specifically delimited to higher education.

The current demands for decolonised education derive from the anger of students at the colonial nature of the university and its primarily "Western” paradigm of values, cultural climate (Manjra 2016), and "Whiteness" (Pilane 2016). For many students, South African universities are an "alienating, overwhelmingly white, Eurocentric space and experience" (Everatt 2016:1). Arguably, it is critically important to understand the acculturation process of these students in such a context, as the consequences of failure to do so might be further violent unrest, and this unrest might go further than burning busses and intimidation of university staff, lecturers and other students (Chiloane 2016). It is acknowledged that higher education institutions are increasing their focus on the acculturation of all students, and improving support services and cultural sensitivity, and we feel that these initiatives should be supported. Given these contextual conditions, this study seeks to better understand acculturation of students in the university context.

Entry into university can therefore be a traumatic experience, but even more so for students hailing from poor family backgrounds who may experience the university as a comparatively alien social economic environment (Stephan, Welman and Jordaan 2004). Black African first year students in South African universities typically experience communicationrelated problems, adverse effects of financial strain, transport problems, housing related problems and the stress of having to live far from university, amongst others (Sennett et al. 2003).

Failure to adapt to university has been found to be related to potentially serious consequences (Pascarella et al. 2004), such as acculturative stress which can manifest in the form of anxiety and depression (Otlu 2010), or confusion, psychosomatic symptoms, feelings 
of alienation and identity confusion, which may ultimately lead to students dropping out of university (Berry et al. 1987). Levels of drop-outs compared to levels of those that persist are therefore dependent on the success or failure of adaptation to university. Key to this process of adjustment, however, is acculturation.

Individual differences in ways of acculturating can be categorised in terms of Berry's four theoretical acculturation strategies, namely integration, assimilation, separation and marginalisation (Berry 2005).

The four strategies at the individual level are portrayed in Figure 1. Although the two dimensions that lead to the acculturation strategies were initially approached from the nondominant group point of view at the individual level, the powerful role played by the dominant group in influencing the way in which non-dominant groups relate has now been factored into acculturation theory (Berry 2010), and this is represented in Figure 2. Figure 2 therefore provides a model that is produced when the public policies and attitudes of the larger society or dominant group are factored in (Sam and Berry 2010). This study locates itself at the individual level.

Issue 1: Maintenance of Heritage Culture and Identity

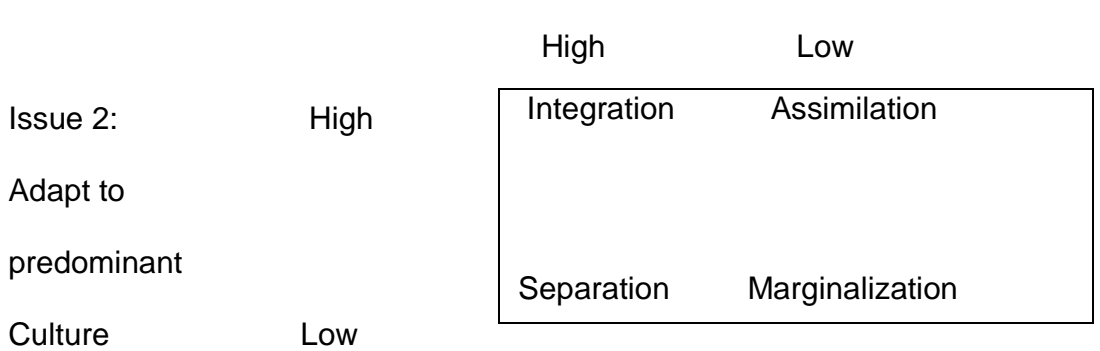

Figure 1: Berry's Acculturation Model: From the perspective of the Individual

Empirical research across a host of contexts suggests integration is most strongly related to positive adaptation outcomes, and is the most preferred (Berry 2010). However, relative preference for assimilation and marginalisation have been found to vary according to ethnic group, the society into which groups have adapted, and the situational domains (Sam and Berry 2010).

Issue 1: Maintenance of Heritage Culture and Identity

\begin{tabular}{llll|} 
& \multicolumn{1}{c}{ High } & Low \\
\cline { 3 - 3 } Issue 2: & High & Multiculturalism & Melting Pot \\
Adapt to & & \\
predominant & & Segregation & Exclusion \\
Culture & Low &
\end{tabular}

Figure 2: Berry's Acculturation Model: From the perspective of the dominant group 
The assimilation strategy relates to the choice of acculturating individuals to shed their own culture or their preference to not maintain their own culture but rather seek to become absorbed in the dominant culture through daily interaction (Berry 2005). Assimilation, however, when sought by the dominant group, leads to the melting pot (Berry 1997).

When individuals choose to maintain their own culture while interacting daily with other groups, the integration strategy results, which to some degree allows them to maintain their cultural integrity (Berry 2005). Better adaptation and lower levels of stress are typically experienced by individuals that pursue the integration strategy (Berry 2005). When the dominant group widely accepts diversity maintenance and equal participation of non-dominant groups in society, multiculturalism results (Berry 2010).

When individuals choose to hold on to their original culture whilst preferring to avoid interaction with the dominant culture, the separation strategy is enacted (Berry 2005). Segregation is said to occur when the dominant group seeks separation (Berry 2010).

Lastly, marginalisation is defined when individuals prefer neither to maintain their own culture nor to interact with other groups (Berry 2005). Marginalisation is also said to entail anxiety and confusion, feelings of alienation and a loss of identity which sometimes leads to acculturative stress (Berry et al. 1987). When such marginalisation is however imposed by the dominant group, exclusion occurs (Berry 2010). Berry (2009) argues that individuals that fall into marginalisation rarely choose it as an option but usually become marginalised as a result of forced assimilation and forced exclusion.

A number of studies in different countries have been undertaken with different acculturating groups to determine preferences for acculturation strategies (Sam and Berry 2010). A study conducted by Berry on 5000 immigrant youth settled in 13 countries examining intercultural variables confirmed Berry's four acculturation strategies of acculturation and found that integration was the most preferred way of acculturating, with 36 per cent of the sample exhibiting the integration pattern (Berry 2010).

What is lacking in this literature, however, is a fuller understanding of the psychological mechanisms through which individuals differ in their choices of acculturation strategy. If psychological mechanisms are at the forefront of these effects, then absent from the above discussions is consideration of the role of personality, which according to literature accounts for a substantial degree of variance in individual behaviour and decision making. It is acknowledged, however, that goals, ideology, rights and other influences also control personal choice, but these are considered to be outside of the ambit of the delimited focus of this study. 
Given the delimited scope of this research, what is also not clear is the extent to which individual personality shapes choices related to acculturation strategies, and how much variance is contributed by group effects. The relationships between certain characteristics of respondents and the reported acculturation strategy of respondents are therefore tested. Included in these individual characteristics are individual personality permutations. Personality and its hypothesised relationships with acculturation are considered as follows.

\section{Personality and acculturation}

Openness to experience relates to intelligence, new ideas, creativity, curiosity (Bhatti et al. 2014), as well as innovativeness, inventiveness, wide interests (Bozionelos 2004), and openness and change tolerance (Vakola, Tsaousis and Nikolaou 2004). As such, it is possible that individuals with higher levels of openness to experience might be expected to be more likely to adapt to other cultures, whether maintaining their own culture or not. This personality dimension has also been found to be associated with openness to new values (Saksvik and Hetland 2009) and lower levels of resistance to change (Oreg 2003; Saksvik and Hetland 2009; Lilford 2014). It is acknowledged that individual-level testing is at a different level than the group-level behaviour exhibited in the FeesMustFall protests. However, as stressed previously, the literature is silent on the relationships between individual-level influences and acculturation, particularly in contexts in which acculturation problems might conceivably be reflected in the protests. Hence, personality is tested as to its relationships with seminal acculturation orientations.

Neuroticism has been found to be related to passivity, hostile reactions, loss or challenges (McCrae and Costa 1986), negative attitudes and higher resistance to change (Oreg 2003; Vakola et al. 2004; Saksvik and Hetland 2009). Arguably, individuals higher in neuroticism might be more likely to suffer from acculturation problems. It is possible individuals experiencing marginalisation may be more likely to join protests, or to register their dissatisfaction with a cultural context perceived as "alien.”

Extraversion is typically associated with activity/stimulation and enjoyment of interpersonal interactions (Vakola et al. 2004), and an energetic and talkative (Bhatti et al. 2014) nature. Extroversion has also been found to be associated with coping mechanisms related to positive thinking and rational action choices (McCrae and Costa 1986). Further, extroversion has also been found to be negatively related to resistance to change (Oreg 2003; Saksvik and Hetland 2009; Lilford 2014).

Conscientiousness, related as it is to self-discipline, responsibility (Grieve and Van 
Deventer 2005), is also typically associated with a "forward looking” and thorough approach to activities (Bhatti et al. 2014). Conscientiousness is expected to be associated with higher investments in acculturation.

Agreeableness, associated with compassion in interpersonal interactions (Vakola et al. 2004), is typically associated with affectionate, sympathetic, friendly, kind and caring characteristics (Bhatti et al. 2014). In addition to these sociable characteristics, agreeableness has been found to be negatively related to resistance to change (Saksvik and Hetland 2009). Agreeableness is therefore considered to potentially be helpful to the acculturation process.

Certain individual factors have been found to be associated with the acculturation process. In terms of individual characteristics, age effects have been found to be associated with acculturation (Yeh 2003; Kuo and Roysircar 2004; Kimbro 2009). Other research has, however, found age to not always influence acculturation relationships (Krause, Bennet and Tran 1989). Age is expected to be associated with time spent adapting, and was included as a variable for analysis. English reading ability was found to predict acculturation (Kuo and Roysircar 2004). English as a home language was included, in order to partition the variance between those with English as a home language and those with other languages given the use of English as the primary language of instruction in the university under study. In terms of differentiation of the lived experience associated with experiences of the country's history, two dummy variable indicators of race were also included, namely binary measures of Black versus non-Black, and Indian versus non-Indian. Black, Indian and Coloured groups experienced the brunt of Apartheid discrimination in contrast to the White group. Given the dummy variable confound, whereby inclusion of all race groups would produce multicollinearity, the White and Coloured groups were excluded, the latter also because of the numbers of respondents required for a balanced sample. Differences in acculturation have been found to be associated with differences in socioeconomic status (Khan, Sobal and Martorell 1997; Kuo and Roysircar 2004). Given the history of the country, questions were also included which sampled whether either of an individual's parents had attended university. Having a parent who had attended university was expected to be positively associated with the effectiveness of acculturation. Residence in a university hostel was also tested, as this was expected to facilitate acculturation through group socialisation effects.

Acculturation has also been found to be related to religiosity (Neff and Hoppe 1993; Gans 1994). Religiosity is considered an important determinant of acculturation, due to its strong group effects. Religiosity can enable successful acculturation through social support networks, enabling integration. The final variable included was therefore whether an individual attended 
a mixed religion school. Having provided an overview of certain literature relating acculturation to personality and certain core individual characteristics, the methods applied in this study are now discussed.

\section{METHODS}

The study applied an empirical research design based on positivist ontological and epistemological assumptions. The study proceeded from assumptions that variance in individual personality and other characteristics that is systematically and objectively related to variance in acculturation choices would be reflected in statistical testing. It was expected that significant associations would provide a basis for the accumulation of evidence against which the predictions of theory could be tested in this context.

\section{Sample and population}

The entire first-year Economics class cohort of a large South African university was sampled. Participation was voluntary. Ethics Committee approval was obtained prior to the study. Of the questionnaires administered, 251 usable responses were obtained. The first-year Economics class was chosen as this is a compulsory first-year subject primarily for commerce and other subjects that were not explicitly related to the teaching of social theory.

\section{Statistical analysis}

On the basis of a review of the literature, the following specification was formulated for testing. In this equation, $\xi_{i}$ represents the acculturation orientation tested as outcome variable (either integration, separation, marginalisation, or assimilation). The intercept term is $a_{i}$, and the error terms is given by $u_{i}$. The term $Z_{i}$ is a vector for all the personality items, namely neuroticism, extraversion, openness, agreeableness, and conscientiousness. $R_{i}$ represents the race variables, namely Black, Indian, and Coloured, in binary variable form. This specification was tested using logistic regression.

$$
\begin{aligned}
& \xi_{i}=a_{i}+Z_{i}+\beta_{4} \text { tropicar }_{i}+\beta_{4} \text { age }_{i}+\beta_{4} \text { English }_{i}+R_{i}+\beta_{4} \text { gender }_{i}+ \\
& \beta_{4} \text { parent }_{i}++\beta_{4} \text { hostel }_{i}+\beta_{4} \text { school }_{i}+u_{i}
\end{aligned}
$$

The second tested specification utilised ordinary least squares (OLS). The same predictor variables were used but the outcome variables were the continuous values of MOC and AUC.

$$
\begin{aligned}
& X_{i}=a_{i}+Z_{i}+\beta_{4} \text { tropicar }_{i}+\beta_{4} \text { age }_{i}+\beta_{4} \text { English }_{i}+R_{i}+\beta_{4} \text { gender }_{i}+ \\
& \beta_{4} \text { parent }_{i}++\beta_{4} \text { hostel }_{i}+\beta_{4} \text { school }_{i}+u_{i}
\end{aligned}
$$


Given that the theoretical framework being tested relates to four acculturation orientations (Berry 2010), the first phase of testing applied logistic regression to test the extent to which personality endowments and individual characteristics predicted membership of each of the four acculturation orientations (Specification 1). The acculturation orientations were developed following Berry's (2010) method of grouping together those respondents (i) high in preference for MOC and high AUC, representing integration, (ii) high MOC and low AUC, representing separation, (iii) low MOC and high AUC, or assimilation, and (iv) low MOC and low AUC, or marginalisation. The second phase of testing sought to test what personality and individual characteristics were associated with the two underlying constructs, namely the preference for MOC versus the preference for AUC (Specification 2). Table 3 reports these results. OLS tests were performed using standard OLS (Models 1 and 4), OLS with bootstrapped standard errors (5000 iterations) (Models 2 and 5) and robust OLS regressions (Models 3 and 6) which controlled for outliers using weighted values. The process of testing therefore sought to test relationships between all six acculturation states, including both the core preferences as well as specific acculturation orientations.

\section{Measures}

Scales were developed to measure the two dimensions of acculturation which measure; (i) the individual's desire to maintain their "home” culture, and (ii) the individual's desire to adapt to the predominant university culture. These were developed based on precedents used in other studies that have conducted research on acculturation and student adjustment, such as the study by Otlu (2010) and other work by Celenk and Van de Vijver's (2011). Content and construct validity (Murphy and Davidshofer 2005) was increased by ensuring the scale items were derived appropriately from theory. Different items were derived to capture different dimensions of the MOC and AUC aspects, to increase the validity of the measures.

\section{DESCRIPTIVE STATISTICS}

The descriptive statistics for the tested variables are reported in Table 1. Mean scores for MOC were found to be higher than AUC. The highest mean for the personality items was for agreeableness, followed by conscientiousness. Just under a third of the respondents had English as a home language. The majority of the sample were female, with about a quarter reporting residence in a university hostel. Almost 85 per cent reported attendance of a mixed religion school. 
Table 1: Descriptive Statistics

\begin{tabular}{|l|c|c|c|c|}
\hline \multicolumn{1}{|c|}{ Variables } & $\begin{array}{c}(\mathbf{1}) \\
\text { Mean }\end{array}$ & $\begin{array}{c}\mathbf{( 3 )} \\
\text { Standard } \\
\text { deviation }\end{array}$ & $\begin{array}{c}\text { (4) } \\
\text { Minimum }\end{array}$ & $\begin{array}{c}\text { (5) } \\
\text { Maximum }\end{array}$ \\
\hline Maintain own culture & 3.770 & 0.597 & 1.4 & 5.2 \\
\hline Adapt university culture & 2.857 & 0.816 & 1 & 5.3 \\
\hline Neuroticism & 3.073 & 0.765 & 1 & 5 \\
\hline Extroversion & 3.931 & 0.872 & 1 & 5.8 \\
\hline Openness & 3.704 & 0.647 & 1.8 & 6 \\
\hline Agreeableness & 4.659 & 0.903 & 1 & 6 \\
\hline Conscientiousness & 4.111 & 0.775 & 1.8 & 6 \\
\hline Age & 18.82 & 1.489 & 0 & 25 \\
\hline English home language (proportion) & 0.321 & 0.468 & 0 & 1 \\
\hline Black & 0.713 & 0.453 & 0 & 1 \\
\hline Coloured & 0.0319 & 0.176 & 0 & 1 \\
\hline Indian & 0.143 & 0.641 & 0 & 9 \\
\hline Gender (proportion male) & 0.412 & 0.493 & 0 & 1 \\
\hline Either parent attended university & 0.532 & 0.500 & 0 & 1 \\
\hline Hostel accommodation & 0.249 & 0.433 & 0 & 1 \\
\hline Mixed religion school & 0.847 & 0.361 & 0 & 1 \\
\hline
\end{tabular}

\section{RESULTS}

This section reports the results of the logistic and OLS regression analyses, with each of the acculturation orientations used as headings to guide the discussions of the results.

\section{Marginalisation}

Individuals with low MOC and low AUC were classified as falling into the marginalisation category according to Berry's typology. With marginalisation as the outcome variable, logistic regression analysis was applied. The exponentiated intercept value was .375 (Wald = 44.078; $\mathrm{p}<.0001$; Standard Error (S.E.) = .148). The -2log likelihood value was 240.797, with a Cox and Snell R Square of .121 and a Nagelkerke R Squared value of .179. This was taken to suggest that almost 18 per cent variability in marginalisation was accounted for by the explanatory variables. The Hosmer and Lemeshow test statistic (Chi2 = 11.193; $\mathrm{df}=8 ; \mathrm{p}<.191$ ) was taken to indicate acceptable model specification. According to the classification table, about 73.6 of the outcomes were able to be predicted, a level over the required 65 per cent threshold.

Results suggest that an increase in age by a year (one unit) is associated with an almost 1.5 times greater likelihood of falling into the marginalisation category, and bring male is associated with a .451 times less likelihood of falling into this category. Agreeableness is negatively associated with marginalisation, but at just outside the five percent level of significance. Consistent with theory (Vakola et al. 2004; Saksvik and Hetland 2009; Bhatti et 
al. 2014) agreeableness might act to buffer individuals against falling into the marginalisation category. It is possible that agreeableness enables acculturation. To ascertain along which dimension agreeableness enables acculturation, the second set of analyses were performed with each axis used as the outcome variable. According to these results (Table 3), agreeableness is a significant predictor of the MOC dimension in Models 4 and 6. Model 6 was taken to be the authoritative model in that outliers were controlled for in this analysis. Being male was found to be a predictor of both AUC and MOC. It is possible that female students are at greater risk of marginalisation in this context, as they are significantly less likely to maintain their own culture or to adapt to the university culture. Support should be given to all students, but with a specific focus on female students who might be more susceptible to marginalisation. In checking which axis is responsible for the strong positive association between age and marginalisation, the robust regression model result indicates that age contributes negatively to MOC. Thus the channel through which age contributes to marginalisation seems to be the weakening of the effects of own culture maintenance. It is possible that older students who are fall into the marginalisation category might be more inclined to act in ways different from their cultural norms, and if they fail to adjust to the university culture they might be more likely to be alienated in this context. University management might do well to provide deeper support for all students, in order to reach these students who might otherwise be difficult to identify. It is possible that disruptive student protests might appeal to these individuals, as marginalisation associated with what might seem an alien culture might make these individuals particularly vulnerable to disruptive behaviours or choices that their cultural orientations would otherwise hold in check. It is acknowledged that these are speculative arguments, but further research is recommended, preferably using causal methods, in order to unearth the causal mechanisms that underlie these findings. Qualitative research might be usefully applied to investigate if those involved in the disruptive aspects of the protests are largely drawn from the ranks of those in this marginalised category.

Table 2: Logistic Regression Results for Acculturation Orientations

\begin{tabular}{|l|c|c|c|c|}
\hline \multicolumn{1}{|c|}{ Variables } & $\begin{array}{c}\mathbf{( 1 )} \\
\text { Integration }\end{array}$ & $\begin{array}{c}\mathbf{( 2 )} \\
\text { Separation }\end{array}$ & $\begin{array}{c}\mathbf{( 3 )} \\
\text { Marginalisation }\end{array}$ & $\begin{array}{c}\text { (4) } \\
\text { Assimilation }\end{array}$ \\
\hline Neuroticism & 0.406 & $-0.506^{\star \star}$ & 0.207 & 0.769 \\
& $(0.255)$ & $(0.212)$ & $(0.237)$ & $(0.577)$ \\
\hline Extraversion & 0.00811 & -0.0504 & -0.0163 & 0.822 \\
& $(0.222)$ & $(0.185)$ & $(0.211)$ & $(0.536)$ \\
\hline Openness & 0.259 & -0.179 & 0.0894 & -0.354 \\
& $(0.288)$ & $(0.238)$ & $(0.266)$ & $(0.567)$ \\
\hline Agreeableness & 0.270 & 0.175 & $-0.353^{\star}$ & -0.438 \\
& $(0.234)$ & $(0.189)$ & $(0.203)$ & $(0.487)$ \\
\hline
\end{tabular}




\begin{tabular}{|c|c|c|c|c|}
\hline Variables & $\begin{array}{c}\text { (1) } \\
\text { Integration }\end{array}$ & $\begin{array}{c}(2) \\
\text { Separation }\end{array}$ & $\begin{array}{c}\text { (3) } \\
\text { Marginalisation }\end{array}$ & $\begin{array}{c}\text { (4) } \\
\text { Assimilation }\end{array}$ \\
\hline Conscientiousness & $\begin{array}{c}0.213 \\
(0.257)\end{array}$ & $\begin{array}{c}0.127 \\
(0.207)\end{array}$ & $\begin{array}{l}-0.330 \\
(0.233)\end{array}$ & $\begin{array}{l}-0.104 \\
(0.560)\end{array}$ \\
\hline Age & $\begin{array}{l}0.0864 \\
(0.195)\end{array}$ & $\begin{array}{l}-0.437^{\star \star} \\
(0.193)\end{array}$ & $\begin{array}{l}0.401^{\star *} \\
(0.188)\end{array}$ & $\begin{array}{c}0.163 \\
(0.454)\end{array}$ \\
\hline English & $\begin{array}{c}0.466 \\
(0.596)\end{array}$ & $\begin{array}{l}-0.392 \\
(0.524)\end{array}$ & $\begin{array}{c}0.148 \\
(0.585)\end{array}$ & $\begin{array}{l}-0.647 \\
(1.407)\end{array}$ \\
\hline Black & $\begin{array}{l}0.0699 \\
(0.673)\end{array}$ & $\begin{array}{l}-0.940 \\
(0.588)\end{array}$ & $\begin{array}{c}1.083 \\
(0.691)\end{array}$ & $\begin{array}{c}0.675 \\
(1.490)\end{array}$ \\
\hline Indian & $\begin{array}{l}-0.0260 \\
(0.316)\end{array}$ & $\begin{array}{l}-0.0291 \\
(0.227)\end{array}$ & $\begin{array}{l}-0.0346 \\
(0.338)\end{array}$ & $\begin{array}{c}0.424 \\
(0.399)\end{array}$ \\
\hline Coloured & $\begin{array}{c}0.713 \\
(0.882)\end{array}$ & $\begin{array}{l}-0.484 \\
(0.848)\end{array}$ & $\begin{array}{l}-0.0806 \\
(1.209)\end{array}$ & \\
\hline Gender (male $=1$ ) & $\begin{array}{c}0.582 \\
(0.382)\end{array}$ & $\begin{array}{c}0.218 \\
(0.316)\end{array}$ & $\begin{array}{l}-0.795^{\star \star} \\
(0.377)\end{array}$ & $\begin{array}{l}-0.0340 \\
(0.829)\end{array}$ \\
\hline $\begin{array}{l}\text { Either parent attended } \\
\text { university }\end{array}$ & $\begin{array}{c}0.443 \\
(0.360)\end{array}$ & $\begin{array}{c}-0.00557 \\
(0.290)\end{array}$ & $\begin{array}{l}-0.389 \\
(0.329)\end{array}$ & $\begin{array}{l}-0.322 \\
(0.749)\end{array}$ \\
\hline Hostel residence & $\begin{array}{c}0.240 \\
(0.432)\end{array}$ & $\begin{array}{c}0.221 \\
(0.352)\end{array}$ & $\begin{array}{l}-0.210 \\
(0.393)\end{array}$ & $\begin{array}{l}-1.516 \\
(1.199)\end{array}$ \\
\hline Attendance of a mixed religion school & 0.173 & $-0.776^{*}$ & 0.803 & 0.995 \\
\hline Constant & $\begin{array}{l}-8.346^{*} \\
(4.539)\end{array}$ & $\begin{array}{l}10.60^{\star \star} \\
(4.420)\end{array}$ & $\begin{array}{l}-7.529^{\star} \\
(4.486)\end{array}$ & $\begin{array}{l}-9.202 \\
(10.86)\end{array}$ \\
\hline Observations & 231 & 231 & 231 & 223 \\
\hline
\end{tabular}

\section{Separation}

Individuals with high MOC but low AUC were categorised as falling into the separation category. With separation as the dependent variable, the exponentiated intercept value was .941 $($ Wald $=212 ; \mathrm{p}<.645$; Standard Error $($ S.E. $)=.132)$. According to the classification table, the model was able to predict about 63.6 of the outcomes, with predictability at just under the 65 per cent threshold.

The -2log likelihood value was 296.158, with a Cox and Snell R Square of .098 and a Nagelkerke R Squared value of .131. About 13 per cent variability in separation was accounted for by the explanatory variables. The Hosmer and Lemeshow test statistic (Chi2 $=7.483 ; \mathrm{df}=8 ; \mathrm{p}<.485$ ) was taken to suggest acceptable model specification.

Neuroticism, age, and attendance of a mixed religion school are found to be negative and significant predictors of the likelihood of falling into the separation explanatory category. Students in the separation category are expected to resist adapting to the university, and to maintain strong cultural bonds. These students might be less likely to join disruptive protests if these (not "normal” protests which are less disruptive) are not aligned with their strong group norms. Religion might be a bonding factor in this instance. If the disruptive protests were aligned with the core norms and values of these groups then they might be expected to become 
involved. The critical factor here is whether the norms of the protests correspond with those of these groups. Unlike marginalised individuals, who might have no "anchor” to their behavioural choices, this group is perhaps expressly linked through their shared values and norms. The mechanism whereby this group does not engage with acculturation to the university culture is unclear, however. Further research might offer causal understandings of these relationships.

It is possible social cohesion may mitigate against neuroticism in this group, in that social bonds may provide reassurance for members. However, it is also possible that individuals high in neuroticism tend to avoid the pressures of high group conformity. Checking of relationships of neuroticism with the AUC and MOC axes suggests that individuals with higher neuroticism are more likely to adapt to the university culture. It is possible that there is something about higher education institutions which are attractive to these individuals. No other acculturation orientation was found to be related to neuroticism.

Younger students might be more likely to maintain the strong bonds of their culture, particularly if they have come from single-religion schools, as they might not have been exposed to alternative cultures. Age might weaken the links of strong cultural bonds, and create marginalisation in individuals who fail to maintain them while not adapting to the university culture. Age is not associated with the integration and assimilation orientations, and seems to only work through the MOC dimension, and negatively so.

Attendance of a single-religion school is found to only act through a negative influence on adaptation to the university culture. Religious values might offer cultural reinforcement but what is not clear here is why these values would be antithetical to the values of a university. Further research might offer more insights into these questions.

\section{Assimilation}

Individuals with low MOC and high AUC were categorised into the assimilation category. With assimilation the dependent variable, the exponentiated intercept value was .041 $($ Wald $=88.871 ; \mathrm{p}<.001 ;$ Standard Error $($ S.E. $)=.340)$. According to the classification table, the model was able to predict about 96.1 of the outcomes, with predictability well over the required 65 per cent threshold.

The -2log likelihood value was 68.041, with a Cox and Snell R Square of .034 and a Nagelkerke R Squared value of .122. About 12 per cent of the variability in assimilation prediction was therefore taken to be accounted for by the explanatory variables. The Hosmer and Lemeshow test statistic $($ Chi2 $=8.53$; $\mathrm{df}=8$; $\mathrm{p}<.384$ ) was taken to suggest acceptable model specification. 
None of the predictor variables were found to be significantly associated with assimilation. This is also the case with integration. What links these two is that both are associated with high AUC. It might be possible that AUC captures a positive response to change, or an adaptive response. Analysis of the contributions of variables to high AUC (Table 3) offers more insight into this state. neuroticism and extraversion are found to be positively related to AUC. It is possible that extraversion enables adaptation to new cultures. Whereas agreeableness and conscientiousness were expected to enable adaptation to a new university culture, these are instead found to positively predict MOC. It might also be possible that these are personality traits more aligned to collectiveness. Further, openness, which was expected to contribute most strongly to adaptation to change and to a new culture (Oreg 2003; Saksvik and Hetland 2009; Lilford 2014) was not found to be significantly associated with either AUC or MOC. Further research is recommended, in order to understand the causal channels through which personality contributes to individual student acculturation choices.

\section{Integration}

Individuals high in MOC as well as AUC were categorised as falling within the integration category. With integration as the dependent variable, the exponentiated intercept value was .255 $($ Wald $=69.732 ; \mathrm{p}<.0001$; Standard Error $($ S.E. $)=.163)$. According to the classification table, the model was able to predict about 79.2 of the outcomes, with predictability over the 65 per cent threshold.

The -2log likelihood value was 223.408, with a Cox and Snell R Square of .042 and a Nagelkerke R squared value of .066. Almost 7 per cent variability in integration was accounted for by the explanatory variables. The Hosmer and Lemeshow test statistic (Chi2 $=11.814 ; \mathrm{df}=8 ; \mathrm{p}<.16$ ) was taken to suggest acceptable model specification.

None of the explanatory variables are found to significantly predict likelihoods of membership of the integration category. This is perhaps reflected in the relatively low Nagelkerke R squared value. As discussed, a commonality underlying both assimilation and integration is they both relate to high AUC. Other variables associated with a high AUC include being male, which predicts both AUC and MOC, but together these effects were not strong enough to manifest in male gender predicting integration. This reflects the finding discussed earlier, that female students may be more likely to experience marginalisation. Attendance of a mixed religion school is also a predictor of higher AUC. It is possible that mixed religion schools are more diverse, and in this way might be a match to the diversity of the academy. 
Table 3: OLS estimations for preferences of Adaptation to University Culture versus Maintain Own Culture

\begin{tabular}{|c|c|c|c|c|c|c|}
\hline Variables & $\begin{array}{c}(\mathbf{1}) \\
\text { TotAUC }\end{array}$ & $\begin{array}{c}(2) \\
\text { TotAUC }\end{array}$ & $\begin{array}{c}(3) \\
\text { TotAUC }\end{array}$ & $\begin{array}{c}(4) \\
\text { TotMOC }\end{array}$ & $\begin{array}{c}\mathbf{( 5 )} \\
\text { TotMOC }\end{array}$ & $\begin{array}{c}(6) \\
\text { TotMOC }\end{array}$ \\
\hline Neuroticism & $\begin{array}{l}0.197^{\star *} \\
(0.0787)\end{array}$ & $\begin{array}{l}0.200^{\star \star} \\
(0.0852)\end{array}$ & $\begin{array}{l}0.218^{\star \star \star} \\
(0.0833)\end{array}$ & $\begin{array}{l}-0.0423 \\
(0.0541)\end{array}$ & $\begin{array}{l}-0.0420 \\
(0.0539)\end{array}$ & $\begin{array}{l}-0.0197 \\
(0.0527)\end{array}$ \\
\hline Extraversion & $\begin{array}{c}0.166^{\star \star} \\
(0.0705)\end{array}$ & $\begin{array}{l}0.173^{\star \star} \\
(0.0792)\end{array}$ & $\begin{array}{l}0.172^{\star \star} \\
(0.0746)\end{array}$ & $\begin{array}{l}0.0285 \\
(0.0480)\end{array}$ & $\begin{array}{l}0.0295 \\
(0.0521)\end{array}$ & $\begin{array}{c}0.0488 \\
(0.0473)\end{array}$ \\
\hline Openness & $\begin{array}{c}0.0518 \\
(0.0910)\end{array}$ & $\begin{array}{c}0.0629 \\
(0.0890)\end{array}$ & $\begin{array}{c}0.0590 \\
(0.0963)\end{array}$ & $\begin{array}{l}0.00751 \\
(0.0616)\end{array}$ & $\begin{array}{l}0.00891 \\
(0.0721)\end{array}$ & $\begin{array}{l}-0.00624 \\
(0.0610)\end{array}$ \\
\hline Agreeableness & $\begin{array}{c}0.0277 \\
(0.0711)\end{array}$ & $\begin{array}{c}0.0293 \\
(0.0887)\end{array}$ & $\begin{array}{c}0.0196 \\
(0.0752)\end{array}$ & $\begin{array}{l}0.108^{\star \star} \\
(0.0489)\end{array}$ & $\begin{array}{c}0.108 \\
(0.0742)\end{array}$ & $\begin{array}{l}0.171^{\star \star \star} \\
(0.0477)\end{array}$ \\
\hline Conscientiousness & $\begin{array}{l}-0.0201 \\
(0.0792)\end{array}$ & $\begin{array}{l}-0.0191 \\
(0.0851)\end{array}$ & $\begin{array}{l}-0.0180 \\
(0.0839)\end{array}$ & $\begin{array}{l}0.148^{\star \star \star} \\
(0.0545)\end{array}$ & $\begin{array}{l}0.148^{\star \star} \\
(0.0635)\end{array}$ & $\begin{array}{l}0.109^{\star \star} \\
(0.0531)\end{array}$ \\
\hline Age & $\begin{array}{c}0.0202 \\
(0.0644)\end{array}$ & $\begin{array}{c}0.0250 \\
(0.0616)\end{array}$ & $\begin{array}{c}0.0291 \\
(0.0681)\end{array}$ & $\begin{array}{l}-0.0636 \\
(0.0440)\end{array}$ & $\begin{array}{l}-0.0630 \\
(0.0451)\end{array}$ & $\begin{array}{l}-0.0870^{\star \star} \\
(0.0431)\end{array}$ \\
\hline $\begin{array}{l}\text { English home } \\
\text { language }\end{array}$ & $\begin{array}{c}0.00551 \\
(0.196)\end{array}$ & $\begin{array}{l}0.0134 \\
(0.208)\end{array}$ & $\begin{array}{l}0.0557 \\
(0.208)\end{array}$ & $\begin{array}{l}-0.135 \\
(0.135)\end{array}$ & $\begin{array}{l}-0.134 \\
(0.173)\end{array}$ & $\begin{array}{l}-0.0165 \\
(0.132)\end{array}$ \\
\hline Black & $\begin{array}{l}-0.177 \\
(0.219)\end{array}$ & $\begin{array}{l}-0.134 \\
(0.224)\end{array}$ & $\begin{array}{l}-0.126 \\
(0.231)\end{array}$ & $\begin{array}{l}-0.336^{\star \star} \\
(0.144)\end{array}$ & $\begin{array}{l}-0.331^{*} \\
(0.188)\end{array}$ & $\begin{array}{l}-0.220 \\
(0.147)\end{array}$ \\
\hline Indian & $\begin{array}{l}-0.0164 \\
(0.0856)\end{array}$ & $\begin{array}{c}-0.00741 \\
(0.141)\end{array}$ & $\begin{array}{l}-0.00826 \\
(0.0906)\end{array}$ & $\begin{array}{l}0.00632 \\
(0.0583)\end{array}$ & $\begin{array}{l}0.00745 \\
(0.0943)\end{array}$ & $\begin{array}{c}0.0151 \\
(0.0574)\end{array}$ \\
\hline Coloured & $\begin{array}{l}-0.226 \\
(0.324)\end{array}$ & & $\begin{array}{l}-0.228 \\
(0.343)\end{array}$ & & $\begin{array}{l}0.0284 \\
(0.195)\end{array}$ & $\begin{array}{l}0.0128 \\
(0.217)\end{array}$ \\
\hline Gender (male $=1$ ) & $\begin{array}{l}0.218^{\star} \\
(0.122)\end{array}$ & $\begin{array}{l}0.219^{\star} \\
(0.125)\end{array}$ & $\begin{array}{l}0.217^{\star} \\
(0.129)\end{array}$ & $\begin{array}{l}0.211^{\star *} \\
(0.0839)\end{array}$ & $\begin{array}{l}0.211^{\star \star} \\
(0.0836)\end{array}$ & $\begin{array}{l}0.252^{\star \star \star} \\
(0.0817)\end{array}$ \\
\hline $\begin{array}{l}\text { Either parent } \\
\text { attended university }\end{array}$ & $\begin{array}{l}-0.0157 \\
(0.112)\end{array}$ & $\begin{array}{l}-0.0266 \\
(0.110)\end{array}$ & $\begin{array}{c}-0.00317 \\
(0.118)\end{array}$ & $\begin{array}{c}0.0769 \\
(0.0761)\end{array}$ & $\begin{array}{c}0.0755 \\
(0.0779)\end{array}$ & $\begin{array}{c}0.105 \\
(0.0749)\end{array}$ \\
\hline Hostel residence & $\begin{array}{c}-0.00885 \\
(0.137)\end{array}$ & $\begin{array}{l}-0.0122 \\
(0.150)\end{array}$ & $\begin{array}{l}-0.0651 \\
(0.145)\end{array}$ & $\begin{array}{l}0.0978 \\
(0.0944)\end{array}$ & $\begin{array}{l}0.0974 \\
(0.0901)\end{array}$ & $\begin{array}{c}0.0361 \\
(0.0920)\end{array}$ \\
\hline $\begin{array}{l}\text { Attendance of a } \\
\text { mixed religion school }\end{array}$ & $\begin{array}{l}0.402^{\star \star \star} \\
(0.154)\end{array}$ & $\begin{array}{l}0.395^{\star \star} \\
(0.185)\end{array}$ & $\begin{array}{l}0.461^{\star \star \star} \\
(0.163)\end{array}$ & $\begin{array}{l}-0.102 \\
(0.106)\end{array}$ & $\begin{array}{l}-0.102 \\
(0.0971)\end{array}$ & $\begin{array}{l}-0.102 \\
(0.103)\end{array}$ \\
\hline Constant & $\begin{array}{c}0.707 \\
(1.496)\end{array}$ & $\begin{array}{c}0.495 \\
(1.446)\end{array}$ & $\begin{array}{c}0.348 \\
(1.583)\end{array}$ & $\begin{array}{l}4.075^{\star \star \star} \\
(1.008)\end{array}$ & $\begin{array}{l}4.049^{\star \star \star} \\
(0.966)\end{array}$ & $\begin{array}{l}4.154^{\star \star \star} \\
(1.003)\end{array}$ \\
\hline Observations & 231 & 231 & 231 & 231 & 231 & 231 \\
\hline R-squared & 0.088 & 0.086 & 0.093 & 0.177 & 0.177 & 0.214 \\
\hline
\end{tabular}

Standard errors in parentheses ${ }^{* *} p<0.01,{ }^{* *} p<0.05,{ }^{*} p<0.1$

In terms of high MOC as a dimension of integration, Black students were more likely to report lower levels of MOC than the rest of the cohort. To the extent that marginalisation relates to low MOC as well as low AUC, it is possible that some aspect of alienation from one's own culture is experienced in this university context. Alienation might be associated with lower levels of MOC, which might not necessarily relate in turn to higher or lower adaptation to the university culture. It is possible that lower MOC might be related to lower normatively directed behaviours or choices, and that alienation associated with low social bonds might make students vulnerable to extra-norm behaviours, or behaviours that are less in accordance with cultural 
norms. Interestingly, parental attendance of university and hostel residence are not found to be significantly associated with either AUC or MOC. These results demonstrate that certain characteristics and personality traits are associated with different acculturation orientations. This is taken to be an important finding in that an individual-level differentiator (personality) is found to predict group level acculturation effects. Further research using multilevel analysis is recommended, in order to further understand the extent to which individual level characteristics can influence group-level acculturation. Having reported and discussed the results of the study, conclusions are now presented.

\section{CONCLUSIONS}

The objective of this research was to test theory that predicted certain determinants of acculturation orientations in the context of a large South African university. This research was considered particularly important in the context of nation-wide student protests, some of which have been disruptive, resulting in the closing of certain institutions for different periods of time. The study sought to understand relationships around the extent to which students classify themselves as marginalised, or experience low maintenance of their own culture and low adjustment to university. Students more likely to fall into the marginalisation category were found to be those older than their peers. Female students are found to be more likely to experience marginalisation. Agreeableness was found to be weakly and negatively associated with marginalisation. Students with a high tendency to maintain their own culture but a low level of acculturation to the university context were considered to fall into the separation category. These students are found to typically be younger, and to have significantly lower levels of neuroticism than their peers. To understand the specific dimensions, or axes of these acculturation orientations, relationships of these determinants with MOC and AUC were tested.

Of the personality dimensions, neuroticism and extraversion were found to significantly and positively predict higher AUC, and agreeableness and conscientiousness to predict higher MOC. It was concluded that agreeableness and conscientiousness might be associated with collective acculturative states. These findings were considered important as they suggest that there is an individual component to acculturation orientations. Further research was recommended, in order to understand relationships of acculturation at the nexus of individual personality and acculturation orientations. Black students were found to be more likely to experience lower levels of own culture maintenance, which might reflect the influence of the university milieu itself, irrespective of whether higher or lower adjustment to the university culture results. MOC is taken to perhaps provide support to individuals in what might be an 
alien context. Being male was found to be related to higher MOC and AUC. Students from single-religion schools were found to be significantly less likely to adjust to the university culture.

This research has shown that individual characteristics might play an important role in student acculturation, and that personality can also perhaps account for certain of the cultural adaptive choices made by students. Although this research could not authoritatively relate different acculturation orientation states to motivations for the student protests, the argument was made that students who are marginalised from the normative support of their peers (low MOC), or fail to adjust to the university culture (low AUC) might be more likely to express dissatisfaction with the university culture. Further research is now needed to investigate whether low MOC or low AUC do indeed contribute to a culture of alienation in our universities, and whether this is a causative factor in the disruptive nature of the student protests experienced across the country over the past two years.

\section{REFERENCES}

Berry, J. W. 1997. Immigration, acculturation and adaptation. Applied Psychology: An International Review 46(1): 5-34.

Berry, John W. 2005. Acculturation: Living successfully in two cultures. International Journal of Intercultural Relations 29(6): 697-712.

Berry, J. W. 2008. Globalisation and acculturation. International Journal of Intercultural Relations 32(4): 328-336.

Berry, J. W. 2010. Intercultural relations and acculturation in the pacific region. Journal of Pacific Rim Psychology 4(2): 95-102.

Berry, J. W. 2011. Integration and multiculturalism: Ways towards social solidarity. Papers on Social Representations 20: 2.1-2.11.

Berry, J. W., U. Kim, T. Minde and D. Mok. 1987. Comparative studies of acculturative stress. International Migration Review 21(3): 491-511.

Bhatti, M. A., M. M. Battour, A. R. Ismail and V. P. Sundram. 2014. Effects of personality traits (big five) on expatriates adjustment and job performance. Equality, Diversity and Inclusion: An International Journal 33(1): 73-96.

Bozionelos, N. 2004. The big five of personality and work involvement. Journal of Managerial Psychology 19(1): 69-81.

Celenk, O. and F. J. R. Van de Vijver. 2011. Assessment of acculturation: Issues and overview of measures. Online Readings in Psychology and Culture 8(1). http://dx.doi.org/10.9707/23070919.1105 (Accessed 13 July 2014).

Chiloane, M. 2016. Wits worker dies after inhaling extinguisher fumes set off during protest. Eyewitness News. $\quad$ http://ewn.co.za/2016/09/26/Wits-worker-dies-after-inhaling-extinguisher-fumes (Accessed 30 October 2016).

ENCA. 2016. Listen: White students' death audio a scare tactic - Wits. https://www.enca.com/southafrica/\%E2\%80\%98it\%E2\%80\%99s-a-scare-tactic\%E2\%80\%99-wits-responds-to-death-audio (Accessed 30 October 2016).

Everatt, D. 2016. What must fall: Fees or the South African state? https://www.enca.com/opinion/whatmust-fall-fees-or-the-south-african-state (Accessed 5 November 2016). 
Feldt, R. C., M. Graham and D. Dew. 2011. Measuring adjustment to college: Construct validity of the Student Adaptation to College Questionnaire. Measurement and Evaluation in Counselling and Development 44: 92-104. doi:10.1177/0748175611400291.

Goba, N. 2016. Fees must fall movement mobilizes taxi industry to join forces with them. http://www.sowetanlive.co.za/news/2016/10/19/fees-must-fall-movement-mobilizes-taxiindustry-to-join-forces-with-them (Accessed 20 October 2016).

Govinder, K. S., N. P. Zondo and M. W. Makgoba. 2013. A new look at demographic transformation for universities in South Africa. South African Journal Science 109(11/12): 1-11.

Gans, H. J. 1994. Symbolic ethnicity and symbolic religiosity: Towards a comparison of ethnic and religious acculturation. Ethnic and Racial Studies 17(4): 577-592.

Grieve, K. and V. van Deventer. 2005. A student's A-Z of Psychology. Lansdowne: Juta and Company.

Jawitz, J. 2016. Unearthing white academics' experience of teaching in higher education in South Africa. Teaching in Higher Education 21(8): 948-961.

Kimbro, R. T. 2009. Acculturation in context: Gender, age at migration, neighbourhood ethnicity, and health behaviors. Social Science Quarterly 90(5): 1145-1166.

Khan, L. K., J. Sobal and R. Martorell. 1997. Acculturation, socioeconomic status, and obesity in Mexican Americans, Cuban American, and Puerto Ricans. International Journal of Obesity and Related Metabolic Disorders 21(2): 91-97.

Lilford, N. 2014. Effect of respondents' personality on resistance to change and the sales force. Journal of Financial Services Marketing 19(2): 155-164.

Kamsteeg, F. and H. Wels. 2012. Traveling ideas: Equality and power play around diversity at NorthWest University (NWU), South Africa. International Journal of Business Anthropology 3(2): 88106.

Krause, N., J. Bennet and T. V. Tran. 1989. Age differences in the acculturation process. Psychology and Aging 4(3): 321-332.

Kuo, B. C. H. and G. Roysircar. 2004. Predictors of acculturation for Chinese adolescents in Canada: Age of arrival, length of stay, social class, and English reading ability. Journal of Multicultural Counselling and Development 32(3): 143-154.

Lodge, T. and B. Nasson. 1991. All, here, and now: Black politics in South Africa in the 1980s. David Phillip: Cape Town.

Manjra, S. 2016. GroundUp analysis: Making sense of the students' protests, their demands and strategies. http://www.dailymaverick.co.za/article/2016-10-09-groundup-analysis-making-senseof-the-students-protests-their-demands-and-strategies/\#.WB3kCtJ97IU (Accessed 5 November 2016).

Manyathela, C. 2016. Malema: The white man has been too comfortable for too long. http://ewn.co.za/2016/11/08/malema-the-white-man-has-been-too-comfortable-for-too-long (Accessed 8 November 2016).

Mapumulo, Z. 2016. Service delivery protests intensifying in run-up to elections. City Press. http://citypress.news24.com/News/service-delivery-protests-intensifying-in-run-up-to-elections-20160603 (Accessed 30 October 2016).

Mashoko, Mpofu, Mushayikwa and M. Keane. 2016. Indigenous knowledge for school science: Insights into the issue of intellectual property rights from three South African studies. Indilinga African Journal of Indigenous Knowledge Systems 15(1): 178-189.

McCrae, R. R. and P. T. Costa. 1986. Personality, coping, and coping effectiveness in an adult sample. Journal of Personality 54(2): 385-404.

Murphy, K. R. and C. O. Davidshofer. 2005. Psychological Testing. $6^{\text {th }}$ Edition. New Jersey: Pearson Education.

Neff, J. A. and S. K. Hoppe. 1993. Race/ethnicity, acculturation, and psychological distress: Fatalism and religiosity as cultural resources. Journal of Community Psychology 21(1): 3-20.

Ngcobo, Z., C. Manyathela and B. Bateman. 2016. FeesMustFall protests turn violent, bus set alight in 
Jhb CBD. http://ewn.co.za/2016/10/10/Bus-set-alight-during-Wits-protests (Accessed 30 October 2016).

Othman, N., F. Nordin, N. Mat Nor, Z. Endot, A. Azmi, I. Ismail and A. Yaakob. 2013. Factors influencing students' academic aspirations in higher institution: A conceptual analysis. ProcediaSocial and Behavioural Sciences 90: 411-420.

Otlu, F. N. 2010. College adjustment of international students: The role of gender, acculturative stress, coping skills, cultural distance, and perceived social support. (Unpublished Master of Science dissertation). Middle East Technical University. http:etd.lib.metu.edu.tr/upload/ 12612769/index.pdf (Accessed 22 April 2014).

Pascarella, E. T., C. T. Pierson, G. C. Wolniak and P. T. Terenzini. 2004. First-generation college students: Additional evidence on college experiences and outcomes. The Journal of Higher Education 75(3): 249-284.

Pilane, P. 2016. Whiteness, not Afrikaans, must fall. Mail and Guardian. http://mg.co.za/article/201603-10-whiteness-not-afrikaans-must-fall (Accessed 5 November 2016).

Pitjeng, R. 2016. The truth behind the death threat rumour at Wits. http://ewn.co.za/2016/10/05/Thetruth-behind-the-death-threat-rumours-at-Wits (Accessed 30 October 2016).

Rhoads, R. A. 1998. Freedom's web: Student activism in an age of cultural diversity. Johns Hopkins University Press: Baltimore.

Sam, D. L. and J. W. Berry. 1995. Acculturative stress among young immigrants in Norway. Scandinavian Journal of Psychology 36(1): 10-24.

Sam, D. L. and J. W. Berry. 2010. Acculturation: When groups of different cultural backgrounds meet. Perspectives on Psychological Science 5(4): 472-481.

Saksvik, I. B. and H. Hetland. 2009. Exploring dispositional resistance to change. Journal of Leadership and Organizational Studies 16(2): 175-183.

Schwartz, S. J. and B. L. Zamboanga. 2008. Testing Berry's model of acculturation: A confirmatory latent class approach. Cultural Diversity and Ethnic Minority Psychology 14: 275-285.

Sennett, J., G. Finchilescu, K. Gibson and R. Strauss. 2003 Adjustment of black students at a historically white South African university. Educational psychology: An International Journal of Experimental Educational Psychology 23(1): 107-116.

Stephen, D. F., J. C. Welman and W. J. Jordaan. 2004. English language proficiency as an indicator of academic performance at a tertiary institution. South African Journal of Human Resource Management 2(3): 42-53.

Stolley, G. 2016. Malema not calling for the slaughter of whites, for now. IOL. http://www.iol.co.za/news/crime-courts/malema-not-calling-for-the-slaughter-of-whites-fornow-2087713 (Accessed 8 November 2016).

Vakola, M., I. Tsaousis and I. Nikolaou. 2004. The role of emotional intelligence and personality variables on attitudes toward organisational change. Journal of Managerial Psychology 19(2): 88110.

Vegter, I. 2014. If Malema isn't Pol Pot, is he still dangerous. Genocide Watch. http://genocidewatch.net/2014/03/19/if-malema-isnt-pol-pot-is-he-still-dangerous/ (Accessed 8 November 2016).

Yeh, C. J. 2003. Age, acculturation, cultural adjustment, and mental health symptoms of Chinese, Korean, and Japanese immigrant youths. Cultural Diversity and Ethnic Minority Psychology 9(1): 34-48. 